\title{
Telemedicine in neurology: current evidence
}

\author{
Telemedicina na neurologia: evidências atuais \\ Renan Barros DOMINGUES ${ }^{1,2}$, Carlos Eduardo MANTESE ${ }^{1,3,4}$, Emanuelle da Silva AQUINO ${ }^{1,3,5}$, \\ Francisca Goreth Malheiro Moraes FANTINI'6, Gilmar Fernandes do PRADO ${ }^{7,8}$, Ricardo NITRINI5,9
}

\begin{abstract}
Background: Telemedicine was first introduced in Neurology as a tool to facilitate access to acute stroke treatment. More recently, evidence has emerged of the use of telemedicine in several other areas of Neurology. With the advent of the COVID-19 pandemic and the need for social isolation, Brazilian authorities have expanded the regulation of the use of telemedicine, thus allowing the treatment of many patients with neurological diseases to be conducted with less risk of SARS-CoV-2 contamination. Objective: This study aimed to critically review the current evidence of the use, efficacy, safety, and usefulness of telemedicine in Neurology. Methods: A review of PubMed indexed articles was carried out by searching for the terms "telemedicine AND": "headache", "multiple sclerosis", "vestibular disorders", "cerebrovascular diseases", "epilepsy”, “neuromuscular diseases”, "dementia”, and "movement disorders”. The more relevant studies in each of these areas were critically analyzed. Results: Several articles were found and analyzed in each of these areas of Neurology. The main described contributions of telemedicine in the diagnosis and treatment of such neurological conditions were presented, indicating a great potential of use of this type of assistance in all these fields. Conclusion: Current evidence supports that teleneurology can be a tool to increase care for patients suffering from neurological diseases.
\end{abstract}

Keywords: Telemedicine; Neurology; Coronavirus Infections; Teleneurology.

\section{RESUMO}

Introdução: A telemedicina surge pela primeira vez na neurologia como uma ferramenta para facilitar o acesso ao tratamento do acidente vascular cerebral (AVC) Agudo. Mais recentemente, inúmeras evidências têm surgido acerca da eficácia e da segurança do uso da telemedicina em várias outras áreas da neurologia. Com o advento da pandemia de COVID-19 e a necessidade de isolamento social, as autoridades brasileiras flexibilizaram a regulamentação da telemedicina, permitindo assim que inúmeros pacientes com doenças neurológicas possam ter acesso ao tratamento, com menor risco de exposição à contaminação pelo SARS-CoV-2. Objetivo: O objetivo deste artigo foi avaliar criticamente as evidências correntes acerca da segurança e eficácia do uso da telemedicina em diversas áreas da neurologia. Métodos: Este artigo foi uma revisão de artigos indexados no PubMed, buscando os termos telemedicina, cefaleias, esclerose múltipla, doenças vestibulares, doenças cerebrovasculares, epilepsia, doenças neuromusculares, demência e desordens do movimento. Os artigos mais relevantes em cada uma das áreas foram criticamente analisados. Resultados: Diversos artigos foram identificados e analisados em todas as áreas anteriormente citadas. Os principais achados quanto às contribuições da telemedicina, para o diagnóstico e tratamento das condições, foram apresentados, indicando potenciais benefícios da telemedicina em todas as áreas buscadas. Conclusão: As evidências atuais indicam que a teleneurologia é uma potencial ferramenta para ampliar o acesso ao cuidado em inúmeras áreas da neurologia.

Palavras-chave: Telemedicina; Neurologia; Infecções por Coronavírus; Teleneurologia.

\footnotetext{
'Comissão Aberta de Telemedicina, Academia Brasileira de Neurologia, São Paulo SP, Brazil.

${ }^{2}$ Santa Casa de Misericórdia de São Paulo, Departamento de Neurologia, São Paulo SP, Brazil.

${ }^{3}$ Hospital Sírio Libanês, Telemedicina, São Paulo SP, Brazil.

${ }^{4}$ Hospital Mãe de Deus, Porto Alegre RS, Brazil.

${ }^{5}$ Universidade de São Paulo, Departamento de Neurologia, São Paulo SP, Brazil.

${ }^{6}$ Comissão de Exercício Profissional, Academia Brasileira de Neurologia, São Paulo SP, Brazil.

${ }^{7}$ Diretoria Executiva, Academia Brasileira de Neurologia, São Paulo SP, Brazil.

${ }^{8}$ Universidade Federal de São Paulo, Departamento de Neurologia, São Paulo SP, Brazil.

${ }^{9}$ Diretoria Científica, Academia Brasileira de Neurologia, São Paulo SP, Brazil.

Renan Barros DOMINGUES (iD https://orcid.org/0000-0002-6058-7937; Carlos Eduardo MANTESE (iD https://orcid.org/0000-0002-8306-803X;

Emanuelle da Silva AQUINO (iD https://orcid.org/0000-0001-6178-5831; Francisca Goreth Malheiro Moraes FANTINI iD https://orcid.org/0000-0002-9632-6253;

Gilmar Fernandes do PRADO (D) https://orcid.org/0000-0002-3383-8198; Ricardo NITRINI (D) https://orcid.org/0000-0002-5721-1525

Correspondence: Renan Barros Domingues; E-mail: contato@renandomingues.med.br

Conflict of interest: There is no conflict of interests to declare.

Received on June 23, 2020; Accepted on July 19, 2020.
} 


\section{INTRODUCTION}

Telemedicine, according to the World Health Organization, means the provision of health services when distance is a critical factor, by professionals who use information and communication technology to exchange valid information for the diagnosis, treatment and prevention of diseases, as well as for research, and the continuing education of professionals. The history of telemedicine begun in the early $20^{\text {th }}$ century, and in 1967 the first structured system was created, integrating the Massachusetts General Hospital with Boston Logan Airport. Since the emergence of the Internet in 1990, the possibilities of telemedicine have expanded and there has been an increase in its use in several areas of Medicine ${ }^{2}$. Telemedicine is used to connect two or more physicians or a physician with a patients, and includes different modalities such as teleconsultation, teleorientation, telemonitoring, screening, and remote reports ${ }^{3}$.

In Brazil, telemedicine was first regulated by the Federal Council of Medicine (CFM) in 2002, by the resolution no. 1,6434. However, several telemedicine procedures, such as teleconsultation, were not regulated until recently. With the advent of the COVID-19 pandemic and the need for social isolation determined by local health authorities, there also emerged a need to regulate these procedures as a way to maintain the provision of medical care, not only for SARS-CoV-2-infected patients but also for those with other medical conditions. This was done through ordinance no. $467^{5}$ of the Ministry of Health and Law no. 13,989 ${ }^{6}$ of March 2020. Meanwhile, the CFM is working along with Brazilian medical specialty societies in order to achieve a broader and more definitive regulation of the practice of telemedicine in Brazil.

In Neurology, telemedicine was first used in the acute management of stroke patients, more than 10 years ago ${ }^{7}$. More recently, other areas of Neurology have been addressed, with controlled studies evaluating the safety, effectiveness, cost-benefit, and satisfaction of patients with the use of telemedicine. The results of these studies have been presented in reviews and official documents of neurological societies ${ }^{8}$. In order to contribute to the ongoing discussions about telemedicine in Brazil, the Brazilian Academy of Neurology (ABN) has created an Open Committee on Telemedicine (CAT-ABN), with the purpose of compiling and analyzing current evidence in teleneurology. This critical review is a result of this initiative and aims to present the current evidence about the use of telemedicine in the care of patients in several areas of Neurology. The literature search was performed in February 2020 and revised in June 2020. Articles were selected by authors, based on their attributed relevance, type, and current evidence in the different areas of Neurology. For each of these areas, we analyzed those studies performed according to the best methodological recommendations. To achieve our goal of properly contributing to a better practice in this field, whenever possible, we retrieved data from well-designed clinical trials.

\section{HEADACHE}

Primary headaches have high prevalence and great impact; however, most of the patients with primary headaches in Brazil are not properly diagnosed and managed ${ }^{9}$. This is also true in other countries, including developed ones $^{10}$. This difficulty in access has encouraged initiatives evaluating the use of telemedicine and teleconsultations in the care of these patients.

The search for the terms "headache AND telemedicine" returned 55 articles in the PubMed database. Many were small group studies, case reports, and e-Health studies evaluating electronic headache diaries and digital tools to improve adherence to treatment. Eleven were considered the most important, since they were controlled clinical trial studies comparing telemedicine with conventional face-to-face appointments ${ }^{11,12,13,14,15}$. Some included all non-acute headache types and some were restricted to specific populations, such as people suffering from migraine and medication-overuse headache $\mathrm{e}^{1,15}$.

The first parameter analyzed in the studies was the effectiveness of telemedicine care when compared to face-to-face interaction in terms of clinical outcomes, such as a reduction in the frequency of headache attacks. The papers showed that the results obtained with the use of telemedicine were not inferior or significantly different from those obtained with face-to-face care as regards the reduction or improvement of attacks measured by scales such as the Migraine Disability Assessment (MIDAS) and the Headache Impact Test (HIT-6), and comorbidities ${ }^{11,14,15,16}$.

Another parameter evaluated was safety in identifying potential secondary headaches. In this regard, the studies showed that after an initial adequate screening carried out by a primary care service physician or an initial consultation with a specialist, patients' follow-up through teleconsultations was comparable to face-to-face care in identifying the need for neuroimaging tests, abnormalities in neuroimaging tests, the need for hospitalization, and headaches due to more serious diseases ${ }^{13,16}$. One study calculated that over 20,000 telemedicine consultations are necessary to miss the diagnosis of one case of secondary headache ${ }^{13}$.

The studies also showed good cost-effectiveness, reduced travel costs, increased access, and high user satisfaction $^{12,15,16}$. Small studies also demonstrated the feasibility of telemedicine in the management of children with primary headaches ${ }^{17,18}$. As yet there are no satisfactory reports on the safety and effectiveness of telemedicine for emergency headache care.

\section{MULTIPLE SCLEROSIS}

The search for the terms "multiple sclerosis AND telemedicine" generated a total of 133 articles via PubMed. 
The aspects evaluated include therapeutic follow-up, remote assessment of functional status, use of technologies to aid in rehabilitation (telerehabilitation), remote neurocognitive assessment, remote psychological interventions, including cognitive-behavioral therapy, mindfulness, and neuropsychological rehabilitation, remote monitoring of activities, and assessment of adherence to medical therapy ${ }^{19,20,21,22,23,24,25,26,27,28,29,30,31,32,33,34,35}$.

With regard to therapeutic follow-up, some small studies showed the potential benefits of telemedicine as regards access to health professionals outside regular office hours, with the convenience of staying at home ${ }^{24,25,26}$. One of them compared face-to-face with telemedicine care in patients recruited at a referral center, showing the latter to be feasible, cost-effective, and appealing to persons with multiple sclerosis (MS) as well as physicians, and supporting its use as an additional tool in the care of MS patients ${ }^{27}$.

The assessment of functional status via telemedicine in patients with MS was analyzed. The expanded disability status scale (EDSS) assessment by telemedicine and by face-to-face evaluation was shown to obtain very close results; however, evaluation of some neurological examination items was found to be inferior by telemedicine, including that of sensitivity, brain stem functions, cerebellum, and functional system ${ }^{28,29}$.

Home rehabilitation with the help of telemedicine showed promise according to some small studies, with increased patient engagement and positive results in variables such as muscle strength and adherence to physical exercise $e^{30,31}$. Telemedicine was tested for neuropsychological and mental health assessment in MS patients ${ }^{32}$. Another study assessed the use of digital tools for neuropsychological rehabilitation in patients with $\mathrm{MS}^{35}$. These studies showed positive contributions of the use of technology both for the evaluation and for rehabilitation of these patients ${ }^{32,35}$.

In general, these investigations indicated the potential of telemedicine to reduce costs and achieve a good level of satisfaction with the use of digital tools, whether by patients, caregivers, or professionals. Therefore, they suggested a positive contribution of telemedicine for the assessment and monitoring of patients with, MS as well as by offering assistance in their rehabilitation, with a complementary role in relation to conventional care.

\section{VESTIBULAR DISORDERS}

The search for the terms "telemedicine AND (dizziness OR vertigo)" returned 25 articles in the PubMed database. Three addressed the applications of telemedicine in the diagnosis of vestibular and balance disorders ${ }^{36,37,38,39}$. Thus, we note that research in this area is still very scarce.

Regarding recurrent vertigo, a study with 37 patients evaluated the use of a video of the patient's eyes during the
Dix-Hallpike maneuver, recorded by smartphone, in the diagnosis of vestibular disorders ${ }^{36}$. Seven patients were diagnosed with BPPV, the sensitivity of the method for this diagnosis being $92.86 \%$ and the specificity $100 \%$.

In the emergency care context, there was a suggestion in the literature for the creation of TeleVertigo systems ${ }^{38}$, to remotely diagnose and manage patients with acute vertigo and dizziness, aiming at diagnostic clarification between peripheral or central origin. This protocol suggestes the use of the quantitative horizontal video head impulse test (vHIT) to assess the vestibule-ocular reflex.

A randomized controlled trial with 322 adults with chronic vestibular syndromes showed that internet-based vestibular rehabilitation resulted in a significant decrease in vestibular symptoms at six months, compared with usual care ${ }^{39}$.

\section{CEREBROVASCULAR DISEASES}

The search for the terms "stroke AND telemedicine" via PubMed generated a total of 1,097 articles. Stroke care is the one of the most frequent and consolidated conditions in the telemedicine-assisted model, having been the first area of Neurology to effectively use and implement telemedicine. The factors that drove telestroke were the need to increase fast access to acute treatment with recombinant tissue plasminogen activator (rt-PA) and the finding that the complication rate with this therapy is higher when it is used by untrained physicians, at the same time that there are not enough trained neurologists to assist stroke patients in all world locations ${ }^{40,41}$.

The demonstration of the effectiveness of telemedicine in the care of stroke patients led to the structuring of stroke networks, many of them adopting telemedicine, with a spokehub model. The spoke is the service, including facilities and personnel, where the patient is assisted. On this site patients are submitted to neuroimaging methods such as non-contrast computed tomography (CT), receive thrombolytic therapy when indicated, and have vital functions managed. The hub is a stroke center, for instance, an academic hospital, with advanced diagnostic and therapeutic capability ${ }^{42,43}$. A deeper review of the specificities of each center involved in a stroke network is beyond the scope of this review; however, the relevance of telemedicine in the structuring and functioning of the stroke networks is clear.

Spoke-hub telestroke was demonstrated to be effective in clinical evaluation using the National Institutes of Health stroke scale (NIHSS) ${ }^{44,45}$, acute stroke triage ${ }^{46}$, evaluation of care quality ${ }^{47}$, evaluation of indications and contraindications of rt-PA use ${ }^{48,49}$, safety measures ${ }^{50}$, costs reduction ${ }^{51}$, and remote neuroradiological evaluation ${ }^{52,53}$. Therefore, the most common use of telemedicine in stroke care is in the acute phase, with physicians utilizing it on the patient's site and remotely to treat patients in the earliest and safest way. 
There are few studies on the use of telemedicine for outpatients with stroke. Most of them refer to its value in improving care, for instance as regards control of the use of anticoagulant drugs, and management of risk factors in patients with previous stroke $e^{54,55}$.

\section{EPILEPSY}

The search for the terms "telemedicine AND epilepsy" generated a total of 107 articles by PubMed. Fifteen were analyzed. Aspects assessed in the studies include: monitoring and management of epilepsy, use of telemedicine for electroencephalogram interpretation, treatment of neuropsychiatric comorbidities, support for diagnosis of epilepsy with non-physicians trained in low-resource settings, prescription and support of diets in the context of epilepsy, and patient support programs.

The studies were of different types, including cross-sectional, cohort, and randomized clinical trials (RCT). In general, their results are promising, generally well evaluated by doctors and patients, and with similar outcomes for conventional and telemedicine groups. An RCT showed that the follow-up of patients with epilepsy can be performed by telephone, with no difference between groups ${ }^{56}$. Another study revealed that the sensitivity and specificity of a structured telephone consultation to detect important clinical events are greater than $90 \%$ in patients with neurocysticercosis epilepsy ${ }^{57}$. A retrospective cohort showed that $43 \%$ of telemedicine consultations resulted in alterations in antiepileptic medication prescriptions, $35 \%$ of which involved discussions about the possibility of epilepsy surgery. Two thirds of the patients were free from attacks or had improved since the last consultation ${ }^{58}$. In a cross-sectional study comparing telemedicine and conventional consultations, no difference was found between the number of seizures, emergency visits or hospitalizations ${ }^{59}$. A study for the diagnosis of epilepsy was carried out in a location without access to specialists, with trained non-doctors, and with telemedicine support. A high level of agreement in relation to face-to-face consultation and a high level of satisfaction were achieved ${ }^{60}$.

Regarding the management of neuropsychiatric comorbidities, online support platforms were found to help in executive dysfunction ${ }^{61}$ and depression ${ }^{62,63}$. Two studies about diet were found, one evaluating the support for adherence to the ketogenic $\operatorname{diet}^{64}$ and another in which the modified Atkins diet was prescribed by email ${ }^{65}$.

Epileptic patients used few digital tools such as software, but they found them easy to use and helpful to improve health behaviors ${ }^{66}$. In addition, multidisciplinary interventions for managing epilepsy with online support were considered useful ${ }^{67,68}$. A study addressing the use of e-text message support revealed that it improved quality of life in the group using this resource ${ }^{69}$. A questionnaire about the use of telemedicine among epileptologists in Canada showed that most consider it important and necessary ${ }^{70}$.

With regard to the help of technology in monitoring and management of epilepsy, several studies point to potential tools. Therefore, the work already published shows promising contributions, providing evidence that management of epilepsy by telemedicine can have outcomes similar to those reached by face-to-face management.

\section{NEUROMUSCULAR DISEASES}

The search for the terms "telemedicine AND neuromuscular" OR "peripheral neuropathy" yielded a total of 47 articles by PubMed. Seven of these were considered more robust and were analyzed. The aspects assessed in the studies include: use of technologies for diagnosis or monitoring of diseases, monitoring of patients, ventilatory support in neuromuscular disorders, and aid in rehabilitation (telerehabilitation). There are few clinical trials in this area.

Most studies were small group or case series. Some showed that remote monitoring of mechanical ventilation is feasible with telemedicine. One demonstrated that monitoring of ventilation by telemedicine may be possible in patients with $\mathrm{ALS}^{71}$ A case series described the management of domestic ventilation $^{72}$. Another study, a randomized clinical trial in patients with ventilatory dysfunction (more than $80 \%$ having neuromuscular causes) showed that starting mechanical ventilation at home was similar to starting it in the hospital with respect to initial monitoring on site or by telemedicine ${ }^{73}$.

A scale was created to assess peripheral neuropathy by telemedicine veterans affairs neuropathy scale (VANS). Specificity and sensitivity were greater than $90 \%$ to identify polyneuropathy ${ }^{74}$. Another study with chemotherapyinduced polyneuropathy patients indicated that telephone monitoring with action protocols led to fewer days of pain and less severe symptoms ${ }^{75}$. A series of four patients with muscular dystrophy was successfully treated with telemedicine $^{76}$. A study assessing psychological care by videoconference for patients with rare neuromuscular diseases showed that telemedicine was able to precisely assess the quality of life in these patients ${ }^{7}$.

Therefore, studies in the area of neuromuscular disease are still lacking in order to assess the full potential of telemedicine in this field. Current studies point out that telemedicine-supported ventilation has great potential. In addition, monitoring patients with neuromuscular diseases seems promising.

\section{DEMENTIA}

The search for the terms "telemedicine AND dementia” returns, by PubMed, a total of 289 articles. The aspects 
evaluated in the studies include the use of telemedicine for the diagnosis of dementia, patients' follow-up, telerehabilitation for cognitive decline, and remote support for dementia caregivers.

Some studies comparing telemedicine with conventional face-to-face assessment focused on diagnostic accuracy and the reliability of the administration of common screening tests. Different cognitive assessment tools were used, including the Mini-Mental State Examination (MMSE), the Geriatric Depression Scale (GDS), the Katz Index of Independence in Activities of Daily Living, the Rowland Universal Dementia Assessment Scale (RUDAS) and the Montreal Cognitive Assessment (MoCA). There were no significant differences between the scores obtained by face-toface and video assessments ${ }^{77,78,79,80,81,82,83}$. A prospective cohort study with 210 patients aged 50 years and older and referred to a memory disorder clinic compared the standard face-toface with videoconference assessment and concluded that the video version was not inferior to the standard version in diagnosing dementia ${ }^{81}$.

In terms of patient outcomes, one study evaluated two groups of patients with dementia during clinical follow-up. One of the groups ( $\mathrm{n}=90$ patients) was followed up in person at a referral center for memory care, and the other ( $\mathrm{n}=98$ patients) was followed up by telemedicine. There was no significant difference in the decline of the MMSE score between the groups studied $^{84}$. Another investigation including 427 patients with dementia compared the duration of treatment of patients evaluated by telemedicine with that of patients visiting a university hospital's dementia clinic, and concluded that the mean duration was significantly longer for the telemedicine group than for the face-to-face assessment group ${ }^{85}$.

A cognitive intervention program using telemedicine versus a conventional face-to-face method was evaluated in a study with twenty-two elderly patients with mild cognitive impairment and mild dementia, and there was similar cognitive improvement in patients in both treatment $\mathrm{arms}^{86}$.

Telephone interventions for family caregivers of people with dementia have been studied and are associated with increased mental and physical health and reduced caregiver burden ${ }^{87,88,89}$.

Different studies show that video consultation is well accepted by both patients and caregivers and is also a way to improve patients' access to memory specialists ${ }^{90,91}$. In general, the studies suggest that telemedicine is a useful and viable alternative for the care of patients with dementia.

\section{MOVEMENT DISORDERS}

The search for the terms "telemedicine AND movement disorders" generated a total of 85 articles by PubMed. Sixteen were analyzed. In addition, references were sought out, resulting in three more articles. The aspects evaluated in the studies include: use of technologies for diagnosis or monitoring of the disease, neurological and psychiatric consultations for patients with movement disorders (teleconsultations) both by computer and mobile devices (tablets), including follow-up of deep brain stimulation (DBS), rehabilitation (telerehabilitation), and a questionnaire on patient and physician satisfaction.

The majority of studies were with Parkinson's disease (PD) patients. In general, they are cohorts or experiments (before and after intervention), without a control group. Most included small groups of patients. Their results were mostly promising and well evaluated by doctors and patients $^{92}$. In a cross-over study using a tablet for teleconsultations compared with regular consultations, PD patients had similar Unified Parkinson's Disease Scale (UPDRS) and Hoen and Yahr (H\&Y) scales ${ }^{93}$. A small clinical trial with PD patients observed better outcomes in quality of life and UPDRS than those observed after regular consultations ${ }^{94}$. Another study showed similar outcomes for the same variables ${ }^{95}$. Another clinical trial with a larger group (total of 86 patients) exhibited a similar level of satisfaction and better UPDRS outcomes ${ }^{96}$. A large randomized clinical trial was carried out with 195 PD individuals followed for one year by teleconsultations or regular consultations and found no difference in quality of life or MDS-UPDRS ${ }^{97}$.

Regarding the DBS follow-up, a series with patients was described ${ }^{9899,100}$. Most studies showed a preference of the patients for the use of telemedicine, in addition to a good evaluation by the doctors. On the other hand, two telerehabilitation studies showed problems with video quality and training time $\mathrm{e}^{101,102}$.

In addition, evaluation through video conferencing of scales UPDRS $^{103}$, Unified Huntington's Disease Scale (UHDRS) ${ }^{104}$ and Abnormal Involuntary Movements Scale (AIMS) ${ }^{105}$ proved similar to face-to-face evaluation. Another test used in the context of movement disorder, Montreal Cognitive Assessment (MoCA) can be applied by online videoconference for patients with $\mathrm{PD}^{106,107}$ and Hungtington's disease ${ }^{106}$.

Psychiatric support for patients with movement disorders by telemedicine showed to have satisfactory evaluations ${ }^{108}$. The telemedicine rehabilitation program for functional disorders seems to improve quality of life as assessed by scales ${ }^{109}$. In addition, a telephone support program appears to improve apathy in patients with PD when compared to controls without a support program ${ }^{110}$.

\section{FINAL REMARKS AND RECOMMENDATIONS}

Telemedicine was incorporated into Neurology due to the need to provide access to acute stroke treatment. The present review has shown that the use of this tool has by now expanded into other areas of Neurology. Telemedicine has proven to be a useful tool which can be employed in a 
complementary or hybrid way along with face-to-face consultations, always aiming at improving care access and increasing patient satisfaction. More studies are needed, among them nationwide studies evaluating the peculiarities of the use of these tools in our population. Telemedicine will never replace face-to face assistance. Instead, it will complement it. A definitive telemedicine regulation will improve the safe practice of telemedicine for the doctors as well as the patients involved. We have included in this review papers dealing with the provision of neurological assistance by neurologists with the use of telemedicine. Teleneurology is and must always be performed by neurologists, following the same principles of quality, commitment, and safety that guide the conventional care provided to all patients in all settings in this specialty.

\section{References}

1. WHO. A health telematics policy in support of WHO's Health-For-All strategy for global health development: report of the WHO group consultation on health telematics, 11-16 December, Geneva, 1997. Geneva, World Health Organization, 1998.

2. Bashshur RL, Howell JD, Krupinski EA, Harms KM, Bashshur N, Doarn CR. The Empirical Foundations of Telemedicine Interventions in Primary Care. Telemed J E Health. 2016 May;22(5):342-75. https:// doi.org/10.1089/tmj.2016.0045

3. Craig J, Patterson V. Introduction to the practice of telemedicine. J Telemed Telecare. 2005 Jan;11(1):3-9. https://doi. org/10.1177/1357633×0501100102

4. Conselho Federal de Medicinal (Brasil). Resolução CFM n 1.643/2002, de 07 de agosto de 2002. Define e disciplina a prestação de serviços através da Telemedicina. Diário Oficial da União, 2002 August 26. Avaliable in: http://www.portalmedico.org.br/resolucoes/ cfm/2002/1643_2002.htm

5. Ministério da Saúde (Brasil). Portaria n 467, de 20 de março de 2020. Dispõe, em caráter excepcional e temporário, sobre as ações de Telemedicina, com o objetivo de regulamentar e operacionalizar as medidas de enfrentamento da emergência de saúde pública de importância internacional previstas no art. $3^{\circ}$ da Lei no 13.979 , de 6 de fevereiro de 2020, decorrente da epidemia de COVID-19. Diário Oficial da União, 2020 August 20. Avaliable in: https://bvsms.saude. gov.br/bvs/saudelegis/gm/2020/prt0467_23_03_2020_extra.html

6. Brasil. Lei no 13.989, de 15 de abril de 2020. Dispõe sobre o uso da telemedicina durante a crise causada pelo coronavírus (SARSCoV-2). Brasília, 2020 August 19. Avaliable in: http://www.planalto. gov.br/ccivil_03/Ato2019-2022/2020/Lei/L13989.htm

7. Mazighi M, Meseguer E, Labreuche J, Miroux P, Le Gall C, Roy P, et al. TRUST-tPA trial:Telemedicine for remote collaboration with urgentists for stroke-tPA treatment. J Telemed Telecare. 2017 Jan;23(1):174-180. https://doi.org/10.1177/1357633×15615762

8. Hatcher-Martin JM, Adams JL, Anderson ER, Bove R, Burrus TM, Chehrenama M, et al. Telemedicine in neurology: Telemedicine Work Group of the American Academy of Neurology update. Neurology. 2020 Jan;94(1):30-38. https://doi.org/10.1212/ wnl.0000000000008708

9. Peres MFP, Oliveira AB, Sarmento EM, Rocha-Filho PS, Peixoto PM, Kowacs F, et al. Public policies in headache disorders: needs and possibilities. Arq Neuropsiquiatr. 2020 Jan;78(1):50-52. https://doi. org/10.1590/0004-282×20190144

10. Katsarava Z, Mania M, Lampl C, Herberhold J, Steiner TJ. Poor medical care for people with migraine in Europe - evidence from the Eurolight study.J Headache Pain. 2018 Feb;19(1):10. https://doi. org/10.1186/s10194-018-0839-1

11. Muller KI, Alstadhaug KB, Bekkelund SI. Telemedicine in the management of non-acute headaches: A prospective, openlabelled non-inferiority, randomised clinical trial. Cephalalgia. 2017 Aug;37(9):855-63. https://doi.org/10.1177/0333102416654885

12. Muller KI, Alstadhaug KB, Bekkelund SI. Headache patients' satisfaction with telemedicine: a 12-month follow-up randomized non-inferiority trial. Eur J Neurol. 2017 Jun;24(6):807-15. https://doi. org/10.1111/ene.13294

13. Muller KI, Alstadhaug KB, Bekkelund SI. A randomized trial of telemedicine efficacy and safety for nonacute headaches. Neurology. 2017 Jul;89(2):153-62. https://doi.org/10.1212/ wnl.0000000000004085

14. Bekkelund SI, Muller KI. Video consultations in medication overuse headache. A randomized controlled trial. Brain Behav. 2019 Jul;9(7):e01344. https://doi.org/10.1002/brb3.1344

15. Friedman DI, Rajan B, Seidmann A. A randomized trial of telemedicine for migraine management. Cephalalgia. 2019 Oct;39(12):1577-85. https://doi.org/10.1177/0333102419868250

16. Domingues RB, Lacerda CB, Silva PDS. Telemedicine in the Management of Primary Headaches: A Critical Review. Headache Medicine. 2019 Dec;10(4):198-202. https://doi.org/10.5935/21787468.20190030

17. Vierhile A, Tuttle J, Adams $\mathrm{H}$, et al. Feasibility of Providing Pediatric Neurology Telemedicine Care to Youth with Headache.J Pediatr Health Care. 2018 Sep-Oct;32(5):500-6. https://doi.org/10.1016/j. pedhc.2018.02.004

18. Qubty W, Patniyot I, Gelfand A. Telemedicine in a pediatric headache clinic: A prospective survey. Neurology. 2018 May;90(19):e1702-5. https://doi.org/10.1212/wnl.0000000000005482

19. Robb JF, Hyland MH, Goodman AD. Comparison of telemedicine versus in-person visits for persons with multiple sclerosis: A randomized crossover study of feasibility, cost, and satisfaction. Mult Scler Relat Disord. 2019 Nov;36:101258. https://doi. org/10.1016/j.msard.2019.05.001

20. Shaw MT, Best P, Frontario A, Charvet LE. Telerehabilitation benefits patients with multiple sclerosis in an urban setting. $J$ Telemed Telecare. 2019 Jul;15:1357633X19861830. https://doi. org/10.1177/1357633×19861830

21. Healey K, Zabad R, Young L, Lindner A, Lenz N, Stewart R, Charlton M. Multiple Sclerosis at Home Access (MAHA): An Initiative to Improve Care in the Community. Int J MS Care 2019 May-Jun;21(3):101-12. https://doi.org/10.7224/1537-2073.2018-006

22. Sesel AL, Sharpe L, Beadnall HN, Barnett MH, Szabo M, Naismith $\mathrm{SL}$. The evaluation of an online mindfulness program for people with multiple sclerosis: study protocol. BMC Neurol 2019 Jun;19(1):129. https://doi.org/10.1186/s12883-019-1356-9

23. Fuchs TA, Ziccardi S, Dwyer MG, Charvet LE, Bartnik A, Campbell R, et al. Response heterogeneity to home-based restorative cognitive rehabilitation in multiple sclerosis: An exploratory study. Mult Scler Relat Disord 2019 Sep;34:103-11. https://doi.org/10.1016/j. msard.2019.06.026

24. Landtblom AM, Guala D, Martin C, Olsson-Hau S, Haghighi S, Jansson L, Fredrikson S. RebiQoL: A randomized trial of telemedicine patient support program for health-related quality of life and adherence in people with MS treated with Rebif. PLoS One 2019 Jul;14(7):e0218453. https://doi.org/10.1371/journal. pone. 0218453 
25. Yeroushalmi S, Maloni H, Costello K, Wallin MT. Telemedicine and Multiple Sclerosis: A Comprehensive Literature Review. J Telemed Telecare. 2019 Aug-Sep;26(7-8):400-13. https://doi. org/10.1177/1357633×19840097

26. Miller DM, Moore SM, Fox RJ, Atreja A, Fu AZ, Lee JC, et al. Webbased selfmanagement for patients with multiple sclerosis: A practical, randomized trial. Telemed J E Health. 2011 Jan-Feb;17(1): 5-13. https://doi.org/10.1089/tmj.2010.0133

27. Mercier HW, Ni P, Houlihan BV, Jette AM. Differential impact and use of a telehealth intervention by persons with MS or SCI. Am J Phys Med Rehabil. 2015 Nov; 94(11): 987-99. https://doi.org/10.1097/ phm.0000000000000291

28. Kane RL, Bever CT, Ehrmantraut M, Forte A, Culpepper WJ, Wallin MT. Teleneurology in patients with multiple sclerosis: EDSS ratings derived remotely and from hands-on examination. J Telemed Telecare. 2008;14(4):190-4.https://doi.org/10.1258/jtt.2008.070904

29. Wood J, Wallin M, Finkelstein J. Can a low-cost webcam be used for a remote neurological exam? Stud Health Technol Inform. 2013;190:30-2. PMID: 23823365.

30. Paul L, Coulter EH, Miller L, McFadyen A, Dorfman J, Mattison PG. Web-based physiotherapy for people moderately affected with Multiple Sclerosis: Quantitative and qualitative data from a randomized, controlled pilot study. Clin Rehabil 2014 Sep;28(9):92435. https://doi.org/10.1177/0269215514527995

31. Tallner A, Streber R, Hentschke C, Morgott M, Geidl W, Mäurer M, Pfeifer K. Internet-supported physical exercise training for persons with multiple sclerosis: A randomised, controlled study. Int J Mol Sci. 2016 Sep;17(10):E1667. https://doi.org/10.3390/ijms17101667

32. Charvet LE, Yang J, Shaw MT, Sherman K, Haider L, Xu J, et al. Cognitive function in multiple sclerosis improves with telerehabilitation: Results from a randomized controlled trial. PLoS One. 2017 May;12(5):e0177177. https://doi.org/10.1371/journal.pone.0177177

33. Moss-Morris R, McCrone P, Yardley L, et al. A pilot randomised controlled trial of an internet-based cognitive behavioural therapy self-management programme (MS Invigor 8) for multiple sclerosis fatigue. Behav Res Ther. 2012 Jun;50(6):415-21. https://doi. org/10.1016/j.brat.2012.03.001

34. Settle JR, Robinson SA, Kane R, Maloni HW, Wallin MT. Remote cognitive assessments for patients with multiple sclerosis: A feasibility study. Mult Scler. 2015 Jul;21(8):1072-9. https://doi. org/10.1177/1352458514559296

35. George MF, Holingue CB, Briggs FB, Shao X, Bellesis KH, Whitmer RA, et al. Feasibility study for remote assessment of cognitive function in multiple sclerosis.J Neurol Neuromed 2016;1(8):10-8. https://doi.org /10.29245/2572.942x/2016/8.1084

36. Shah MU, Lotterman S, Roberts D, Eisen M. Smartphone telemedical emergency department consults for screening of nonacute dizziness. Laryngoscope. 2019 Feb;129(2):466-9. https://doi. org/10.1002/lary. 27424

37. Viirre E, Warner D, Balch D, Nelson JR. Remote medical consultation for vestibular disorders: technological solutions and case report. Telemed J. 1997;3(1):53-8. https://doi.org/doi:10.1089/ tmj.1.1997.3.53

38. Müller-Barna P, Hubert ND, Bergner C, Schütt-Becker N, Rambold H, Haberl RL, et al. TeleVertigo: Diagnosing Stroke in Acute Dizziness: A Telemedicine-Supported Approach. Stroke. 2019 Nov;50(11):3293-8. http://doi.org/10.1161/STROKEAHA.119.026505

39. van Vugt VA, van der Wouden JC, Essery R, Yardley L, Twisk JWR, van der Horst $\mathrm{HE}$, et al. Internet based vestibular rehabilitation with and without physiotherapy support for adults aged 50 and older with a chronic vestibular syndrome in general practice: three armed randomised controlled trial. BMJ. 2019 Nov;367:15922. https://doi. org/10.1136/bmj.l5922

40. Levine SR, Gorman M. "Telestroke”: the application of telemedicine for stroke. Stroke. 1999 Feb;30(2):464-9. https://doi.org/10.1161/01. str.30.2.464
41. Meyer BC, Raman R, Hemmen T, Obler R, Zivin JA, Rao R, et al. Efficacy of site-independent telemedicine in the STRokE DOC trial: a randomised, blinded, prospective study. Lancet Neurol 2008 Sep;7(9):787-95. https://doi.org/10.1016/s1474-4422(08)70171-6

42. Hess DC, Audebert HJ. The history and future of telestroke. Nat Rev Neurol. 2013 Jun;9(6):340-50. https://doi.org/10.1038/ nrneurol.2013.86

43. Silva GS, Farrell S, Shandra E, Viswanathan A, Schwamm LH. The status of telestroke in the United States: a survey of currently active stroke telemedicine programs. Stroke. 2012 Aug;43(8):2078-85. https://doi.org/10.1161/strokeaha.111.645861

44. Anderson ER, Smith B, Ido M, Frankel M. Remote assessment of stroke using the iPhone 4. J Stroke Cerebrovasc Dis. 2013 May;22(4):340-4. https://doi.org/10.1016/j. jstrokecerebrovasdis.2011.09.013

45. Demaerschalk BM, Vegunta S, Vargas BB, Wu Q, Channer DD, Hentz JG. Reliability of real-time video smartphone for assessing National Institutes of Health Stroke Scale scores in acute stroke patients. Stroke 2012 Dec;43(12):3271-7. https://doi.org/10.1161/ strokeaha.112.669150

46. Pervez MA, Silva G, Masrur S, Betensky RA, Furie KL, Hidalgo R, et al. Remote supervision of IV-tPA for acute ischemic stroke by telemedicine or telephone before transfer to a regional stroke center is feasible and safe. Stroke. 2010;41:e18-24. https://doi.org/10.1161/ strokeaha.109.560169

47. Audebert HJ, Wimmer ML, Hahn R, Schenkel J, Bogdahn U, Horn $\mathrm{M}$, et al. Can telemedicine contribute to fulfill WHO Helsingborg Declaration of specialized stroke care? Cerebrovasc Dis. 2005;20(5):362-9. https://doi.org/10.1159/000088064

48. Yang JP, Wu TC, Tegeler C, Xian Y, Olson DM, Kolls BJ. Targeting telestroke: benchmarking time performance in telestroke consultations. J Stroke Cerebrovasc Dis. 2013 May;22(4):470-5. https://doi.org/10.1016/j.jstrokecerebrovasdis.2013.03.010

49. Amorim E, Shih MM, Koehler SA, Massaro LL, Zaidi SF, Jumaa $M A$, et al. Impact of telemedicine implementation in thrombolytic use for acute ischemic stroke: the University of Pittsburgh Medical Center telestroke network experience. J Stroke Cerebrovasc Dis. 2013 May;22(4):527-31. https://doi.org/10.1016/j. jstrokecerebrovasdis.2013.02.004

50. Wahlgren N, Ahmed N, Dávalos A, Ford GA, Grond M, Hacke W, et al. Thrombolysis with alteplase for acute ischaemic stroke in the Safe Implementation of Thrombolysis in Stroke-Monitoring Study (SITSMOST): an observational study. Lancet. 2007 Jan;369(9558):27582. https://doi.org/10.1016/s0140-6736(07)60149-4

51. Miley ML, Demaerschalk BM, Olmstead NL, Kiernan TE, Corday DA, Chikani $\mathrm{V}$, et al. The state of emergency stroke resources and care in rural Arizona: a platform for telemedicine. Telemed J E Health. 2009 Sep;15 (7):691-9. https://doi.org/10.1089/tmj.2009.0018

52. Demaerschalk BM. Telestrokologists: Treating stroke patients here, there, and everywhere with telemedicine. Semin Neurol. 2010 (Nov);30(5):477-91. https://doi.org/10.1055/s-0030-1268869

53. Dharmasaroja PA, Muengtaweepongsa S, Kommarkg U. Implementation of telemedicine and stroke network in thrombolytic administration: Comparison between walk-in and referred patients. Neurocrit Care. 2010 Aug;13(1):62-6. https://doi.org/10.1007/ s12028-010-9360-3

54. Jhaveri MM, Benjamin-Garner R, Rianon N, Sherer M, Francisco $\mathrm{G}$, Vahidy, et al. Telemedicine-guided education on secondary stroke and fall prevention following inpatient rehabilitation for Texas patients with stroke and their caregivers: a feasibility pilot study. BMJ Open. 2017 Sep;7(9):e017340. https://doi.org/10.1136/ bmjopen-2017-017340

55. Liu S, Feng W, Chhatbar PY, Liu Y, Ji X, Ovbiagele B. Mobile health as a viable strategy to enhance stroke risk factor control: A systematic review and meta-analysis. J Neurol Sci. 2017 Jul;378:140-5. https:// doi.org/10.1016/j.jns.2017.04.050 
56. Bahrani K, Singh MB, Bhatia R, Prasad K, Vibha D, Shukla G, et al. Telephonic review for outpatients with epilepsy-A prospective randomized, parallel group study. Seizure. 2017 Dec;53:55-61. https://doi.org/10.1016/j.seizure.2017.11.003

57. Konanki R, Gulati S, Prasad K, Saini L, Pandey RM, Paul VK. Comparison of telephone with face to face consultation for follow up of Neurocysticercosis. Epilepsy Res. 2018 Sep;145:110-5. doi: https:// doi.org/10.1016/j.eplepsyres.2018.06.005

58. Haddad N, Grant I, Eswaran H. Telemedicine for patients with epilepsy: a pilot experience. Epilepsy Behav 2015 Mar;44:1-4. https:// doi.org/10.1016/j.yebeh.2014.11.033

59. Rasmusson KA, Hartshorn JC. A comparison of epilepsy patients in a traditional ambulatory clinic and a telemedieine clinic. Epilepsia. 2005 May;46(5):767-70. https://doi.org/10.1111/j.15281167.2005.44804.x

60. Rajbhandari H, Joshi S, Malakar S, Paudel P, Jain P, Uppadaya K, et al. Epilepsy field workers, a smartphone application and telephone telemedicine: Safe and effective epilepsy care in rural Nepal. Seizure. 2019 Jan;64:54-8. https://doi.org/10.1016/j.seizure.2018.12.005

61. Modi AC, Mara CA, Schmidt M, Smith AW, Turnier L, Glaser N. Epilepsy Journey: A proof of concept trial of a Web-based executive functioning intervention for adolescents with epilepsy. Epilepsia. 2019 Sep;60(9):1895-907. https://doi.org/10.1111/epi.16317

62. Meyer B, Weiss M, Holtkamp M, Arnold S, Brückner K, Schröder J, et al. Effects of an epilepsy-specific Internet intervention (Emyna) on depression: Results of the ENCODE randomized controlled trial. Epilepsia. 2019 Apr;60(4):656-68. https://doi.org/10.1111/epi.14673

63. Thompson NJ, Patel AH, Selwa LM, Stoll SC, Begley CE, Johnson EK, et al. Expanding the efficacy of Project UPLIFT: Distance delivery of mindfulness-based depression prevention to people with epilepsy. J Consult Clin Psychol. 2015 Apr;83(2):304-13. https://doi.org/10.1037/ a0038404

64. Zini EM, Tagliabue A, Trentani C, Ferraris C, Boninsegna R, Quaglini S, et al. An mHealth Application for Educating and Monitoring Patients Treated with a Ketogenic Diet Regimen. Stud Health Technol Inform. 2018;247:481-5. https://doi.org/10.3233/978-1-61499-852-5-481

65. Cervenka MC, Terao NN, Bosarge JL, Henry BJ, Klees AA, Morrison PF, et al. E-mail management of the modified Atkins Diet for adults with epilepsy is feasible and effective. Epilepsia. 2012 Apr;53(4):728-32. https://doi.org/10.1111/j.1528-1167.2012.03406.x

66. Leenen LAM, Wijnen BFM, de Kinderen RJA, van Heugten CM, Evers SMAA, Majoie MHJM. Are people with epilepsy using eHealth-tools?. Epilepsy Behav. 2016 Nov;64(Pt A):268-72. https://doi.org/10.1016/j. yebeh.2016.08.007

67. Sajatovic M, Colon-Zimmermann K, Kahriman M, Fuentes-Casiano E, Liu H, Tatsuoka C, et al. A 6-month prospective randomized controlled trial of remotely delivered group format epilepsy self-management versus waitlist control for high-risk people with epilepsy. Epilepsia. 2018 Sep; 59(9):1684-95. https://doi.org/10.1111/epi.14527

68. Leenen LAM, Wijnen BFM, van Haastregt JCM, de Kinderen RJA, Evers SMAA, Majoie MHJM, et al. Process evaluation of a multicomponent self-management intervention for adults with epilepsy (ZMILE study). Epilepsy Behav. 2017 Aug;73:64-70. https://doi. org/10.1016/j.yebeh.2017.05.023

69. Lua PL, Neni WS. Health-related quality of life improvement via telemedicine for epilepsy: printed versus SMS-based education intervention. Qual Life Res. 2013 Oct;22(8):2123-32. https://doi. org/10.1007/s11136-013-0352-6

70. Ahmed SN, Wiebe S, Mann C, Ohinmaa A. Telemedicine and epilepsy care - a Canada wide survey. J Neurol Sci, 2010 Nov; 37(6):814-8. https://doi.org/10.1017/s0317167100051490

71. de Almeida JP, Pinto AC, Pereira J, Pinto S, de Carvalho M. Implementation of a wireless device for real-time telemedical assistance of home-ventilated amyotrophic lateral sclerosis patients: a feasibility study. Telemed J E Health. 2010 Oct;16(8):8838. https://doi.org/10.1089/tmj.2010.0042
72. Zamarrón C, Morete E, González F. Telemedicine system for the care of patients with neuromuscular disease and chronic respiratory failure. Arch Med Sci. 2014 Oct 27;10(5):1047-51. https://doi. org/10.5114/aoms.2014.46223

73. Hazenberg A, Kerstjens HA, Prins SC, Vermeulen KM, Wijkstra PJ. Initiation of home mechanical ventilation at home: a randomised controlled trial of efficacy, feasibility and costs. Respir Med. 2014 Sep;108(9):1387-95. https://doi.org/10.1016/j.rmed.2014.07.008

74. Wilson AM, Ong MK, Saliba D, Jamal N. The Veterans Affairs Neuropathy Scale: A Reliable, Remote Polyneuropathy Exam. Front Neurol. 2019 Nov;10:1050. https://doi.org/10.3389/fneur.2019.01050

75. 5- Kolb NA, Smith AG, Singleton JR, Beck SL, Howard D, Dittus K, et al. Chemotherapy-related neuropathic symptom management: a randomized trial of an automated symptom-monitoring system paired with nurse practitioner follow-up. Support Care Cancer. 2018 May;26(5):1607-15. https://doi.org/10.1007/s00520-017-3970-7

76. Portaro S, Calabrò RS, Bramanti P, Silvestri G, Torrisi M, ContiNibali V, et al. Telemedicine for Facio-Scapulo-Humeral Muscular Dystrophy: A multidisciplinary approach to improve quality of life and reduce hospitalization rate? Disabil Health J. 2018 Apr;11(2):306-9. https://doi.org/10.1016/j.dhjo.2017.09.003

77. Martínez O, Jometón A, Pérez M, Lázaro E, Amayra I, López-Paz JF, et al. Effectiveness of teleassistance at improving quality of life in people with neuromuscular diseases. Span J Psychol. 2014 Dec;17:E86. https://doi.org/10.1017/sjp.2014.89

78. Shores MM, Ryan-Dykes P, Williams RM, Mamerto B, Sadak T, Pascualy M, e al. Identifying undiagnosed dementia in residential care veterans: comparing telemedicine to in-person clinical examination. Int J Geriatr Psychiatry. 2004 Feb;19(2):101-8. https:// doi.org/10.1002/gps.1029

79. Loh PK, Donaldson M, Flicker L, Maher S, Goldswain P. Development of a telemedicine protocol for the diagnosis of Alzheimer's disease. J Telemed Telecare. 2007;13(2):90-4. https://doi. org/10.1258/135763307780096159

80. Ciemins EL, Holloway B, Coon PJ, McClosky-Armstrong T, Min SJ. Telemedicine and the mini-mental state examination: assessment from a distance. Telemed J E Health. 2009 Jun;15(5):476-8. https:// doi.org/10.1089/tmj.2008.0144

81. Martin-Khan M, Flicker L, Wootton R, Loh PK, Edwards H, Varghese $P$, et al. The diagnostic accuracy of telegeriatrics for the diagnosis of dementia via video conferencing. J Am Med Dir Assoc. 2012 Jun;13(5):487.e19-24 https://doi.org/10.1016/j.jamda.2012.03.004

82. Wong L, Martin-Khan M, Rowland J, Varghese P, Gray LC. The Rowland Universal Dementia Assessment Scale (RUDAS) as a reliable screening tool for dementia when administered via videoconferencing in elderly post-acute hospital patients. J Telemed Telecare. 2012 Abr;18(3):176-9. https://doi.org/10.1258/jtt.2012. sft113

83. Lindauer A, Seelye A, Lyons B, Dodge HH, Mattek N, Mincks K, et al. Dementia Care Comes Home: Patient and Caregiver Assessment via Telemedicine. Gerontologist. 2017 Oct;57(5):e85-93. https://doi. org/10.1093/geront/gnw206

84. Kim H, Jhoo JH, Jang JW. The effect of telemedicine on cognitive decline in patients with dementia. J Telemed Telecare. 2017 Jan;23(1):149-54. https://doi.org/10.1177/1357633×15615049

85. Cheong CK, Lim KH, Jang JW, Jhoo JH. The effect of telemedicine on the duration of treatment in dementia patients. J Telemed Telecare. 2015 Jun;21(4):214-8.https//doi.org/10.1177/1357633X14566571

86. Poon P, Hui E, Dai D, Kwok T, Woo J. Cognitive intervention for community-dwelling older persons with memory problems: telemedicine versus face-to-face treatment. Int J Geriatr Psychiatry. 2005 Mar;20(3):285-6. https://doi.org/10.1002/gps.1282

87. Wilz G, Reder M, Meichsner F, Soellner R. The Tele.TAnDem Intervention: Telephone-based CBT for Family Caregivers of People With Dementia. Gerontologist. 2018 Mar;58(2):e118-129. https://doi. org/10.1093/geront/gnx183 
88. Griffiths PC, Kovaleva M, Higgins M, Langston AH, Hepburn K. Tele-Savvy: An Online Program for Dementia Caregivers. Am J Alzheimers Dis Other Demen. 2018 Aug;33(5):269-76. https://doi. org/10.1177/1533317518755331

89. Lindauer A, McKenzie G, LaFazia D, McNeill L, Mincks K, Spoden N, et al. Using Technology to Facilitate Fidelity Assessments: The Tele-STAR Caregiver Intervention. J Med Internet Res. 2019 May;21(5):e13599. https://doi.org/10.2196/13599

90. Barton C, Morris R, Rothlind J, Yaffe K. Video-telemedicine in a memory disorders clinic: evaluation and management of rural elders with cognitive impairment. Telemed J E Health. 2011 Dec;17(10):78993. https://doi.org/10.1089/tmj.2011.0083

91. Dang S, Gomez-Orozco CA, van Zuilen MH, Levis S. Providing Dementia Consultations to Veterans Using Clinical Video Telehealth: Results from a Clinical Demonstration Project. Telemed J E Health. 2018 Mar;24(3):203-9. https://doi.org/10.1089/tmj.2017.0089

92. Hanson RE, Truesdell M, Stebbins GT, Weathers AL, Goetz CG. Telemedicine vs Office Visits in a Movement Disorders Clinic: Comparative Satisfaction of Physicians and Patients. Mov Disord Clin Pract. 2018 Dec;6(1):65-9. https://doi.org/10.1002/mdc3.12703

93. Sekimoto S, Oyama G, Hatano T, Sasaki F, Nakamura R, Jo T, et al. A Randomized Crossover Pilot Study of Telemedicine Delivered via iPads in Parkinson's Disease. Parkinsons Dis. 2019 Jan;2019:9403295. https://doi.org/10.1155/2019/9403295

94. Dorsey ER, Deuel LM, Voss TS, Finnigan K, George BP, Eason S, et al. Increasing access to specialty care: a pilot, randomized controlled trial of telemedicine for Parkinson's disease. Mov Disord. 2010 Aug;25(11):1652-9. https://doi.org/10.1002/mds.23145

95. Dorsey ER, Venkataraman V, Grana MJ, Bull MT, George BP, Boyd CM, et al. Randomized controlled clinical trial of "virtual house calls" for Parkinson disease. JAMA Neurol. 2013 May;70(5):565-70. https://doi. org/10.1001/jamaneurol.2013.123

96. Wilkinson JR, Spindler M, Wood SM, Marcus SC, Weintraub D, Morley JF, et al. High patient satisfaction with telehealth in Parkinson disease: A randomized controlled study. Neurol Clin Pract. 2016 Jun;6(3):241-51. https://doi.org/10.1212/cpj.0000000000000252

97. Beck CA, Beran DB, Biglan KM, Boyd CM, Dorsey ER, Schmidt PN, et al. National randomized controlled trial of virtual house calls for Parkinson disease. Neurology. 2017 Sep;89(11):1152-61. https://doi. org/10.1212/wnl.0000000000004357

98. Chen Y, Hao H, Chen H, Li L. The study on a telemedicine interaction mode for deep brain stimulation postoperative follow-up. Conf Proc IEEE Eng Med Biol Soc. 2015;2015:186-9. https://doi.org/10.1109/ embc.2015.7318331

99. Chen Y, Hao H, Chen H, Tian Y, Li L. The study on a real-time remote monitoring system for Parkinson's disease patients with deep brain stimulators. Conf Proc IEEE Eng Med Biol Soc. 2014;2014:1358-61. https://doi.org/10.1109/embc.2014.6943851
100. Jitkritsadakul O, Rajalingam R, Toenjes C, Munhoz RP, Fasano A. Telehealth for patients with deep brain stimulation: The experience of the Ontario Telemedicine Network. Mov Disord. 2018 Mar;33(3):4912. https://doi.org/10.1002/mds.27230

101. Engbers L, Bloo H, Kleissen R, Spoelstra J, Vollenbroek-Hutten M. Development of a teleconsultation system for communication between physiotherapists concerning children with complex m.ovement and postural disorders J Telemed Telecare. 2003;9(6):339-43. https://doi.org/10.1258/135763303771005243

102. Visser JJ, Bloo JK, Grobbe FA, Vollenbroek-Hutten MM. Implementation of a broadband video consultation service for children with posture and movement disorders. J Telemed Telecare. 2009;15(6):269-74. http://doi.org/10.1258/jtt.2009.081214

103. Hubble JP, Pahwa R, Michalek DK, Thomas C, Koller WC. Interactive video conferencing: a means of providing interim care to Parkinson's disease patients. Mov Disord. 1993 Jul;8(3):380-2. https://doi. org/10.1002/mds.870080326

104. Bull MT, Darwin K, Venkataraman V, Wagner J, Beck CA, Dorsey ER, et al. A pilot study of virtual visits in Huntington disease. Journal of Huntington's disease. J Huntingtons Dis. 2014;3:189-95. https://doi. org/10.3233/jhd-140102

105. Amarendran V, George A, Gersappe V, Krishnaswamy S, Warren C. The reliability of telepsychiatry for a neuropsychiatric assessment. Telemed J E Health. 2011 Apr;17(3):223-5. https://doi.org/10.1089/ tmj.2010.0144

106. Abdolahi A, Bull MT, Darwin KC, Venkataraman V, Grana MJ, Dorsey ER, et al. A feasibility study of conducting the Montreal Cognitive Assessment remotely in individuals with movement disorders. ealth Informatics J. 2016 Jun;22(2):304-11. doi: 10.1177/1460458214556373. https://doi. org/10.1177/1460458214556373

107. Stillerova T, Liddle J, Gustafsson L, Lamont R, Silburn P. Could everyday technology improve access to assessments? A pilot study on the feasibility of screening cognition in people with Parkinson's disease using the Montreal Cognitive Assessment via Internet videoconferencing. Aust Occup Ther J. 2016 Dec;63(6):373-80. https://doi.org/10.1111/1440-1630.12288

108. Seritan AL, Heiry M, losif AM, Dodge M, Ostrem JL. Telepsychiatry for patients with movement disorders: a feasibility and patient satisfaction study. J Clin Mov Disord. 2019 Jun;6:1. doi: https://doi. org/10.1186/s40734-019-0077-y

109. Demartini B, Bombieri F, Goeta D, Gambini O, Ricciardi L, Tinazzi M. A physical therapy programme for functional motor symptoms: A telemedicine pilot study. Parkinsonism Relat Disord. 2020 Jul;76:108-11. https://doi.org/10.1016/j.parkreldis.2019.05.004

110. Butterfield LC, Cimino CR, Salazar R, Sanchez-Ramos J, Bowers D, Okun MS. The Parkinson's Active Living (PAL) Program.J Geriatr Psychiatry Neurol. 2017 Jan;30(1):11-25. https://doi. org/10.1177/0891988716673467 